\title{
Freddie's Story
}

\author{
Stella Brewer
}

Freddie is a three-year-old chimpanzee born wild in the forests of Guinea. Some time in 1980 his mother was murdered so that Freddie could be sold on the black market. His captor shut him in a plywood box and firmly nailed down the lid. Barely able to move in this confined space, Freddie endured endless dusty hours of travel on the rough bush roads. He was fed any leftovers that could be pushed through the small opening in the side of his prison. Unable to move very much he was forced to sit in his own excrement and as a result his anus became badly infected. He also developed gingivitis, a painful condition which causes the gums to recede and become soft and tender.

In November Freddie's captor smuggled him into the Gambia with the hope of selling him. But word reached the Wildlife Conservation Department, and Freddie was siezed under the Wildlife Conservation Act 1977. By this time Freddie was suffering from severe stress as well as his physical ailments. However, with kindness and understanding, a regular balanced diet and medical attention, his health improved and his distrust and hatred of humans began to give way to hesitant confidence. Slowly his remarkably good-natured personality began to emerge. Each day he was taken for long walks in the Abuko Nature Reserve, where he was free to climb and forage for wild foods. It was planned that as soon as he was well enough he would join a chimpanzee rehabilitation project, where, with others like him, he would be equipped to live independently in the wild.

Just at the time that Freddie was recovering, an Austrian animal dealer, who was also owner of a 'pet shop' and a 'private zoo', visited the Wildlife Conservation Department and enquired whether it was permitted to buy and export chimpanzees and other primates; he was told it was illegal.* Despite this, when he saw Freddie's enclosure he asked it he could photograph him and also whether Freddie was for sale. He was told, rather more emphatically than before, that the Gambian law totally forbade such sales. He returned to Vienna the following day.

On February $l$ at about three o'clock in the morning a single scream was heard from Freddie's enclosure, and by the time someone got there the enclosure was empty. Soon afterwards a car door slammed and a car on the main road accelerated violently away with the escaping thief or thieves. For almost two weeks searches and investigations continued, but to no avail, and it was concluded that whoever had stolen Freddie had fled the country.

We all felt tremendous frustration and despair. But on February 17 the Director of the Wildlife Conservation Department, Eddie Brewer, was shown an Austrian newspaper article describing an incident on the Montana Austria flight from Yundum International Airport, Gambia, on February 1, only hours after Freddie had been stolen. This said that a passenger had gone to the Gambia on a Montana Austria package holiday, taking a three-month-old Dalmatian puppy which he carried in a large basket as cabin luggage. About two days before the end of his stay in the Gambia, he had been seen by two * 67 countries, including the Gambia, have now ratified the CITES which forbids all trade in chimpanzees, so the black market price is high. 
Montana Air stewardess attempting to abandon the puppy on a deserted beach near Fajara. By persistent threatening he had managed to drive it away and hurriedly departed. The stewardesses hastened to rescue the bewildered and cowering puppy, which they kept and took with them on their return flight to Austria on February 1. Shortly after their flight had taken off, one of the stewardesses recognised a passenger as the man she had seen abandoning the puppy on the beach. At his feet was the same large basket that had contained the puppy on the outward flight from Vienna. The captain, Hans Jorge Stockl, was told, and at Vienna Airport, before the passengers had disembarked, Captain Stockl confronted the man and demanded to examine the contents of the basket. This was reluctantly conceded. In the basket lay a drugged infant chimpanzee. At this point the man completely lost his self control and physically attacked the captain, in the presence of 164 other passengers.

On reading this account $\mathrm{Mr}$ Brewer immediately sent a cable to the Chief of Police in Vienna with details of Freddie's theft and followed this with a letter describing the dealer's previous visit to the Gambia. Letters also went to the Director of WWF-Austria seeking his assistance, and the Inspector General of Police for Gambia requested Interpol support. The net began to close around him. Two Austrians who had stayed in the Gambia for three weeks over Christmas, and frequently accompanied Freddie on his daily walks, went to Vienna and were able positively to identify the confiscated chimp as Freddie; DrFaust, Director of Frankfurt Zoo, was instrumental in having Freddie sent to the care and security of Vienna State Zoo. Finally came a cable to say that, following judicial action against the dealer, Freddie would be returned to the Gambia and that the Austrian WWF, assisted by Austria's largest newspaper Kronenzeitung, would cover the cost.

Stella Brewer, of the Gambia, in West Africa, is well known for her work on rehabilitating chimpanzees, which she described in her book The Forest Dwellers, 1978 (Collins).

\section{Million-Acre Park for Saudi Arabia}

Saudi Arabia's first national park, now being planned, will cover one million acres, and range from the Red Sea coral reefs to the mountain peaks. The area, to the south and west of the town of Abha, north of the North Yemen border, is at the point where African and Asian fauna and flora overlap. Botanically it is the best part of Saudi Arabia, being relatively moist with many little known African plants. A team from the US National Park Service is helping in the planning stage, and started a two-year stint in Saudi Arabia in January this year at the expense of the Saudi Government. The Herbarium at Kew will help with plant identifications. The American team would welcome information about the area's wildlife, which should be sent to Ivan D. Miller, US Rep/Jecor, PO Box 216, APO New York 09671, USA.

\section{Worst Incident in Europe}

"The worst oiling in terms of numbers of birds affected that has ever happened in Europe' is the verdict of Chris Meade, of the BTO (British Trust for Ornithology), on the Skagerrak incident over the New Year; and four more serious oilings occurred in the following two weeks. The ringed birds among the deaths show that the northern and western populations of Scotland breeding auks, mainly guillemots and razorbills that were the worst hit. Because most of the birds were immature the oilings are likely to affect the breeding populations in a few years. 